\title{
SCIENTIFIC RESEARCH AND AGRICULTURE*
}

\author{
By Sir Thomas Middleton, K.C.I.E., K.B.E., C.B., F.R.S.
}

$\mathrm{W}$ HEN, in 1912, Section M held its first meeting, my presidential address was upon the early improvers of husbandry, and I referred especially to the assistance given to agriculture through the societies and associations formed by them for promoting experiments and discussion. Section M was the latest addition to associations of the kind, and we who were then present looked forward with expectation to the benefit agricultural science would get from the formation of the new section. In spite of the calamity of the War of 1914-18 and the unrest in the world which has since developed, I feel sure that, in returning to Dundee where that first meeting was held twenty-seven years ago, all will agree that the hopes then formed have been more than fulfilled by the progress of Section M.

My purpose in selecting the motto "Practice with Science" is not to use it as an occasion for a review, but so that I may refer to matters affecting the present circumstances of both partners in the motto. The existence of Section M is in itself a proof of the large amount of scientific work now being carried out on behalf of agriculture, and also of the interest which the scientific public take in the subject. Although it has many shortcomings, as the workers concerned will be the first to admit, it may be claimed for agricultural science that it has prospered and is prospering; in contrast, everywhere there is evidence of the difficulties of agricultural practice.

With subsidies, price-insurance and other measures of the kind for assisting agriculture which at present occupy so much of the farmer's thoughts, the majority of scientific workers have no direct concern. The remedies for agriculture's handicaps. which they have to offer depend on research, and fortunately research is a remedy so widely approved that, when it does arouse criticism, the complaint usually is that too little use is made of it and that the financial resources provided are too meagre.

For criticism of the kind there is, no doubt, justification ; but in the past thirty years, scientific research in agriculture has made great progress in Great Britain, and the prospects for further progress are now better than they ever have been. The subjects under investigation at our research

- From Part II of the presidential address entitled "Practice with Science", Section M (Agriculture) of the British Association, delivered at Dundee on August 31 . institutes and university departments of agriculture are so numerous that the time at my disposal would not permit me to comment on them in any adequate way. My remarks on the scientific workers' programmes must necessarily be of a very restricted kind.

As for meagre financial resources, no one can be more conscious of the needs and demands of the scientific worker than I am. During long years in Whitehall, I have many times reflected that the doctrines of Malthus, confounded though they may be by twentieth-century birth statistics, are peculiarly applicable to agricultural science; the pressure of its annual recruits on the means of subsistence has given me many an anxious hour. Yet when I look back to the first years of the century, when Hall, Russell, Percival and Theobald were breaking new ground at Wye, when Wood and Biffen were making the reputation of the Cambridge School of Agriculture, when Somerville had already shown how pasture improvement may be effected and measured, it is not the meagre. ness, but the growth of the resources now available to the agricultural worker that impress me. For I recall that, in the first report to be written by me in Whitehall Place, $I$ had to point out that for the purpose of experimental work and research the State had granted no more than $£ 380$, whereas in the present year the Development Fund, which Mr. Lloyd George provided for us in 1909, is assisting the scientific worker in agriculture, and through him the British public, to the extent of some $£ 500,000$; and the Development Fund, although much the most important, is not the only source of funds available.

It is questionable if the general public realizes how largely the programmes of the agricultural investigator are framed in the interests of the nation as a whole. Indeed, if these programmes were framed solely for the farmer's benefit, some who have read my doleful account of the difficulties caused to the unhappy farmer by surfeited markets, may suppose that my remedy would be trans. ference of the millstone of surplus from the shoulders of the producer to the neck of the scientific worker! But although fully conscious of the large increase in world production recently brought about as a result of the activities of plant breeders, chemists, pathologists and others, I trust you will not think my logic faulty if I disclaim any such idea. 
Take, for example, the benefits that both agriculture and nutrition would derive from discoveries that would improve the health of farm livestock. By raising the standard of health in domestic animals we would meet some of the most insistent demands of nutrition experts. It is generally agreed that nothing would do more to reduce the number of C3's among us than an increase in the consumption of milk and eggs; it is generally claimed, too, that to secure increased consumption, prices must be less than they now are, and I believe it will be held by those who have studied costs of production that the possibility of lowering prices depends first and foremost on improving the health of the cow and the hen. So long as the wastage in dairy herds and poultry flocks remains at the present level, it is difficult to see how the cost of milk and eggs could be much reduced. To a less extent, perhaps, but still to a substantial degree, the cost of other animal products is increased by the ravages of disease on our flocks and herds.

It was the extent of these losses to the stock owner, and their effect on the food supply of the public, that led the Agricultural Research Council, soon after it was established in 1931 and had surveyed the tasks confronting it, to decide that its main effort in the immediate future should aim at effecting an improvement in the health of farm animals.

With this object in view the Council formed technical committees which brought together for joint study those already engaged in the investigation of a number of diseases of special importance. It made grants for assisting research in numerous cases where additional funds were necessary. It employed trained surveyors to visit stock-raising districts in which diseases, especially those of an obscure kind, were prevalent, and in this way collected much fresh information on the incidence of disease. Experience gained in work of the kind pointed to the need for a central field station at which it would be possible to carry out investigations on selected diseases on a large scale and under farm conditions. For this purpose the Council has acquired an estate of about 1,500 acres, and this is being provided with laboratories, houses for the breeding of laboratory animals and isolated cattle sheds for accommodating animals under investigation.

The work of the Council on animals is paralleled by the assistance it provides for investigational work on farm crops. Committees of specialist workers have been set up, for example, on virus diseases, on plant diseases due to helminth attack and on insecticides and fungicides. One very active committee has been that on the Preservation of Grass and other Fodder Crops. Nost of the special grants made by the Council for work on crops are in aid of pathological investigations. Until 1911 very little attention was given to crop diseases in Great Britain, but when the Development Act provided funds, entomologists and mycologists were added to the staffs of most agricultural institutions and, as research workers or advisory officers, they have since given muchneeded help to agriculture and horticulture ; thus the increase in fruit growing and other forms of horticulture that has taken place in recent years has been stimulated by the researches of plant pathologists and, as in the case of animal products, the nutritional demands of the public are being successfully met because of the invaluable aid which the scientific worker is able to give to the producer. Some of the best examples of "Practice with Science" that the country can show to-day may be found in the orchards of Kent and other apple-growing countics.

So far I have referred to matters that engage the attention of the scientific worker, while agriculture follows what has been called 'its natural lines'; but unhappily for us, our peaceful art must face the problems raised by war, and although opinions have been expressed, and expressed freely on the subject in recent months, it cannot be said that there is any agreement on the role that agriculture either should, or could, be expected to fill in the event of war. Recent discussions, and my own experience in attempting to increase home produce during the War of 1914-18, lead me, therefore, now to refer to the scientific workers' programme in connexion with home food production.

In recent discussions on this subject, advocates of storage, of increased shipping for transport and of increased tillage for home production have all been heard, but too frequently as advocates of rival methods of providing supplies in war. It cannot be stated too strongly that these methods are in no sense rivals. All the aid that each can give would be wanted in a war of long duration. In the early stages of a war, stores would be of especial value, throughout the period of hostilities all the tonnage which could be made available for the carriage of human and animal foodstuffs would certainly be wanted, and in the later stages of a long war reliance might have to be placed largely on home supplies.

It may be accepted, I think, that in any emergency, while every effort would be made to maintain our normal diet, chief anxiety would be caused by the position of energy-supplying foods, in practice our breadstuffs. It was generally recognized during 1914-18 that the comparative absence of food difficulties then experienced was due to the circumstance that breadstuffs were not rationed. 
In the pre-war years 1909-13 Great Britain was producing about 35 per cent of its energy requirements; in 1918 the food production campaign succeeded in raising the home supply to about 42 per cent. Entering the war with home supplies that would have maintained us for 125 days, we produced in 1918 the equivalent of 155 days' normal needs. Because of lack of labour, machinery and implements the difficulties we faced were extreme. With the number of tractors now available, grassland could be broken up rapidly ; but it is one thing to break up grassland and quite another thing to farm it properly, and it is the farming, rather than the breaking up, that calls for careful preparatory work.

But why break up grassland? That was the question asked in 1915 and 1916 ; it caused much controversy and will do so again.

The answer is that, of human food of the kind which we should chiefly want in war, other crops produce much more than grass. In "Food Production in War" I have given many figures in support of this opinion which I need not cite here: one general statement will suffice. In the years 1909-13 the soils of the United Kingdom maintained a population of about $15 \frac{1}{2}$ millions. I estimated that less than one-third of this total had been maintained by our 34 million acres of cultivated grassland (that is, had been provided with the million Calories per person per annum necessary), and that more than two-thirds had been maintained by our 13 million acres under crops other than grass. Per 100 acres of land, 12 and 80 persons respectively had been provided for. These figures, though they relate to the energy value of foods only and not to other things which are essential in our diet, give a fairly correct idea of the relative importance of grass and other crops in providing war rations. The chief reason for the very low production shown by grass is that a large percentage of our grassland is of poor quality and is grazed by store cattle and shcep. For the average pasture grazed by dairy cows my figure was 41 persons maintained per 100 acres; well-managed grass carrying good cows might indeed provide the energy needs of 75-80 persons per 100 acres.

Our present systems of husbandry took form long before the acroplane had to be reckoned with and they may be regarded as suitable for conditions that until recently existed, but I cannot agree that, as Europe now is, we should remain satisfied with methods of farming that, in war, would leave us dependent for some 65 per cent of our food supply on imports. My personal view is that, for defence reasons, we must change to a more flexible method of farming than that which is now commonly followed, that we should adopt a system which under peace conditions would provide from 35 to 40 per cent of our requirements and in an emergency would enable us rapidly to increase food production to a figure providing about half our annual needs. The change which, for defence reasons, I now advocate is that for which my predecessor argued at Cambridge on grounds of good farming, namely, a change over from permanent to temporary grass.

Sir George Stapledon advocated ley farming on an extensive scale. The adoption of this system would in his view improve the output of nearly all English cultivated grassland. For the purpose I suggest above, it would not be necessary to replace more than from four to five million acres of permanent grass by temporary leys. If, say, $4 \frac{1}{2}$ million acres were thus converted, Great Britain would then have $16 \frac{1}{2}$ million acres under arable cultivation as it had fifty years ago. About 40 per cent of the cultivated area would still remain under permanent grass, so that, in selecting the area for conversion into temporary leys, a wide choice would be available.

The substitution of temporary for permanent grass need not, in itself, call for substantial changes in the character of the land's output. The grassland would, as Sir George Stapledon stated, carry more stock, and if stock were paying better than crops the main change in output under peace conditions would be an increase in livestock products. From the point of view of war farming the advantages of temporary leys are obvious. The use of the plough and of other implements would be familiar to farmers cultivating temporary leys, but in many cases would be quite unfamiliar to those occupying only permanent grass. Tillage implements, would be available on the farms on which they would be required in an emergency and the quality of the land itself for tillage purposes would be well known; thus, in an emergency, arrangements for corn growing could quickly and easily be made.

In spite of the advantages to both the country and the farmer which can be claimed for ley farming, it must be recognized that in England there are circumstances which strongly tend to check the spread of the system. Permanent grass growing is the well.established custom of the country; the change over from tillage to grass farming saved many from bankruptcy at the end of the nineteenth century, and since that time grazing has, on the whole, been a safer business than agriculture. Again, short of capital as farmers are, it would take a good deal of courage to expend $£ 3$ to $£ 7$ per acre in forming a temporary ley, even if arithmetic proved that a return of 10 to 20 per cent on the outlay may be expected over a period of years. The confidence of farmers 
in the future has been undermined as a result of their experiences since the War of 1914-18, and much will depend on the extent to which confidence can be restored as a result of the Government's recent policy.

What is now called for is intensive research at a central station on the many questions that would arise in connexion with the conversion of permanent into temporary grassland, together with a close study of local conditions, favourable and unfavourable, for the extension of ley farming, by economists and other scientific workers in different parts of the country. Sir George Stapledon himself is at some pains to explain that he is not an economist; all the more need that we should put the economist on his tracks! He has already persuaded a number of farmers to adopt his advice, and the results secured by men who have successfully turned from permanent to temporary grass farming would be of much value. Relatively the number of men concerned may be small, but I believe that they are sufficiently numerous to provide us with guidance of a kind that we cannot afford to neglect.

There are, indeed, features in the present situation which suggest that there is much scope for the economist, and not only in connexion with the interpretation of the experiences of grass growers. All readers of agricultural journals know that, in spite of agriculture's depressed state, there are within the industry many enterprising men who are doing well both for themselves and for their land. Their methods are certainly worth study and exposition, and the audience waits. Thanks to such movements as the Young Farmers' Clubs and to the facilities for training provided by Farm Institutes, there are now in Great Britain a large number of lads and young men keenly interested in agricultural progress and anxious to learn. Economic studies of the methods of successful men would be welcomed by these learners and by them would be translated into practice later on. The young farmers of my genera. tion learned chiefly by example, and no doubt the young farmers of to-day continue to do so; but to-day, much more than formerly, they are so trained as to welcome precept, if precept is based on economic studies of the kind I have in view. Thus in the process of converting some four or five million acres now in permanent grass into temporary pastures, which would be necessary to fit England to respond rapidly, as Scotland already can, to the call for increased food supplies, I lay much stress on the assistance which the economist can give.

The awakening of the soil, which would follow the breaking up of permanent grassland, would intensify the programmes of most other scientific workers and in some cases would call for substantially increased activity. This would be the case especially in agricultural enginecring. Whether in tilling a larger area in normal times, or in rapidly extending the tillage area in war, no form of aid would be more welcome to the farmer than aid in selecting and employing machines and.implements that would enable him to use manual labour to advantage.

Many other matters would call for the attention of the scientific worker in war; some of them could be predicted because of 1914-18 experience, others could not, for one thing learned in 1914-18 was that war throws up new and unexpected problems. On the precise nature of these problems we need not now speculate; rather let us note that the scientific worker is confronted with one very definite objective. This objective, which must be approached from different angles, may, in a sentence, be stated to be the preparation of British agriculture to expand its normal output of food rapidly if called upon to do so. The immediate aim should be the provision of a six months' supply of food for the nation in an emergency.

Many of those who have considered the subject of food supply in war would not agree with the views I express ; they would point to agricultural experience in recent years and argue that the production of half the nation's food from the soils of Great Britain would be impossible. But while I admit that experience since, 1919 has not been encouraging, my view is that our present tendency is to underestimate the capacity of our agriculture, and I claim that our outlook should not be restricted by the experience of the past twenty years.

There is little amiss with the soils, or the climate, of Britain ; our tillage land responded well to the calls made on it a century ago and would respond again. Our farmers taught those of most other countries, and if their pupils are now, in some cases, ahead of them, there is no lack of farming talent. Research and education in agriculture have been with us for a generation; growth may have been slow at first, but advances are now being made at a rate that is encouraging, and we may confidently expect much more aid from science in future than it has given us since 1919. Thus, from the technical point of view, I see no insuperable difficulties in the programme I have outlined.

From the point of view of farmers themselves, however, the case is otherwise. If they and their employees are to earn as meagre a share of the national income in future as they have done in the past twenty years, a further decline in the arable area is only too likely, for the reason that, under recent conditions, masters and men have lost confidence in their future prospects. 
There is an atmosphere of 'defeatism' about, and not only among agriculturists themselves. There is too ready an acceptance of the doctrine that economic changes have condemned the land of England to slumber under grass, and that economic reasons forbid its awakening by the plough. As matters are, it would certainly cost the nation money to bring several millions of acres back into arable cultivation and to substitute temporary for permanent pastures; but if the change were made, not only would we add largely to the agricultural output, but also there is at least a prospect that farmers would find themselves better off than they now are. In my judgment the ease with which tolerably good grass can be grown in many parts of England has led far too many farmers to bury their talents under the green sod, and too many farmers, as well as thër counsellors, believe that it is prudent to leave these talents buried; but looking to the future I am satisfied that good and faithful service to the country calls for a change, and, I hope, for a change that would be rewarded. To science I look for assistance in bringing this change about and, for the farmer's reward, to the belief that the world's non-agricultural inhabitants cannot expect a continuation of the conditions which, during the past century, have enabled them to buy their food at less than cost price. But these conditions may not. quickly alter, while changes in farming are needed now, and as I have admitted that the nation must pay before large changes in our methods of cultivation can be expected, I will be asked : Why should the nation pay ?

Whatever the next year or two may hold in store, Britain, hateful as the prospect may be, cannot afford to neglect preparations for defence. In these preparations agriculture must have a place. How large this place should be is a matter of opinion. My personal view, based on experience gained during 1914-18, is that it should have a large place; but be its place large or small, it is for services rendered in connexion with defence that farmers can legitimately ask the nation to pay, as it is paying, and paying heavily, for the services of others similarly engaged.

Thus looking to the future I conclude that the century-old motto which heads my paper is still applicable ; the nation which relied on the British farmer for its food supply in 1839 cannot do without his aid in 1939; while he himself, if he is to do his part as his forefathers did, must take as his watchword "Practice with Science".

\section{NUCLEAR REACTIONS IN STELLAR EVOLUTION* \\ By Prof. G. Gamow, GEORGE WASHingtoN University, WASHington, D.C.}

(3). Apart from the stars of the main sequence, there is known a large class of stars having very high luminosities but possessing much lower effective temperatures (that is, much greater radii) than the stars of the main sequence of the same luminositics. In the Hertzsprung-Russell diagram these so-called red giants form a rather irregularly distributed group on the upper right side of the main sequence. Because of anomalously large radii these red giants possess very low densities, and the estimated central temperatures are considerably lower than those for the stars of the main sequence (for typical red giants the central densities can be as low as $5 \times 10^{-7} \mathrm{gm} . / \mathrm{cm} .^{3}$, and central temperatures less than $1 \times 10^{\circ} \mathrm{C}$.). Thus it is clear at once that the energy production in these stars cannot be due to the same nuclear reaction as in the stars of the main sequence, and we have to look for reactions taking place at an appreciable rate at much lower temperatures than the carbon-nitrogen cycle. From Table I [p. 575]

*Continued from page $\mathbf{5 7}$. we see that the nuclei which can be responsibie for the energy production at lower temperatures are the isotopes of heavy hydrogen, lithium, beryllium and boron, and, using the data of this table together with formula (1), it is easy to estimate at which temperatures these different processes will be of importance. Then, using the homology transformations, we can calculate the location of stars with different energy-producing reactions in the Hertzsprung-Russell diagram ${ }^{8}$.

The result of such calculations shows that stars with different energy-producing reactions should be located within different rather broad bands running parallel to the main sequence. The central lines of these various bands are shown in Fig. 2 together with the central line of the main sequence. It is interesting to notice that, whereas the bands corresponding to the reactions of the isotopes of hydrogen and lithium are very close together, the bands of ${ }^{10} \mathrm{~B}$ and ${ }^{11} \mathrm{~B}$ are widely separated. This comes from the fact that the two isotopes of boron lead to quite different nuclear reactions, one being 